POLITYKA ENERGETYCZNA - ENERGY POLICY JOURNAL

$2020 \diamond$ Volume $23 \uparrow$ Issue $3 \uparrow 147-164$

DOI: $10.33223 / \mathrm{epj} / 127921$

\author{
Iryna SotnyK ${ }^{1}$, Daniil Hulak ${ }^{2}$, Oleksandr YaKushev ${ }^{3}$, Oksana YaKusheva $^{4}$, \\ Olha V. Prokopenko ${ }^{5}$, Andrii YeVdokymov ${ }^{6}$
}

\title{
Development of the US electric car market: macroeconomic determinants and forecasts
}

ABSTRACT: In the article, mathematical modeling methods are used to study the main trends and macroeconomic determinants of the electric car market development in 2011-2018 on the example of the US. The determinants include economic (GDP), socio-economic (household income), energy (electricity use), and environmental $\left(\mathrm{CO}_{2}\right.$ emissions) factors. The authors justify the role of electric transport in strengthening national energy security due to the transition to renewable energy technologies and the reduction of fossil fuel use. Based on the constructed linear regression equations, a weak relationship has been revealed between the number of electric vehicles sold and the environmental factor, which

$\triangle$ Corresponding Author: Olha V. Prokopenko; e-mail: prokopenko.olha.w@gmail.com

${ }^{1}$ Department of Economics, Entrepreneurship and Business Administration, Sumy State University, Sumy, Ukraine; ORCID iD: 0000-0001-5787-2481; e-mail: insotnik@gmail.com

2 Department of Labor Organization, Rationing and Remuneration, PJSC «Cherkasyoblenergo», Ukraine; ORCID iD: 0000-0001-8840-3557; e-mail: danielckua@gmail.com

3 Department of Management and Business Administration, Cherkasy State Technological University, Cherkasy, Ukraine; ORCID iD: 0000-0002-0699-1795; e-mail: aleksandro@i.ua

${ }^{4}$ Department of Economics and Management, Cherkasy State Technological University, Cherkasy, Ukraine; ORCID iD: 0000-0002-4849-0323; e-mail: o.yakusheva14@gmail.com

5 Department of Economics, Collegium Mazovia Innovative University, Siedlce, Poland; ORCID iD: 0000-00031362-478X; e-mail: prokopenko.olha.w@gmail.com

${ }^{6}$ Department of Economics, Entrepreneurship and Business Administration, Sumy State University, Sumy, Ukraine; ORCID iD: 0000-0002-2491-0557; e-mail: evdokimov_a@ukr.net

2020. The Author(s). This is an open-access article distributed under the terms of the Creative Commons Attribution-ShareAlike International License (CC BY-SA 4.0, http://creativecommons.org/licenses/by-sa/4.0/), which permits use, distribution, and reproduction in any medium, provided that the Article is properly cited. 
can be explained by the small share of electric cars in the US market. The formed multifactor linear model showed a positive impact of both the country's GDP growth and electricity consumption increase on the number of electric vehicles sold. However, the rise in household incomes negatively influences market development due to insufficient consumer awareness of the electric transport operation benefits, an underdeveloped network of electric vehicle charging stations, etc. Based on the obtained multifactor model, the authors have built optimistic, optimal and pessimistic scenarios for the US electric vehicle market deployment for the next five years. In order to implement the most favorable scenarios, recommendations for market development factors' management have been made. The results of the study can be used to improve public policy in the US transport and energy sectors, as well as in other countries to optimize the fuel and energy balance, strengthen the energy independence of states by developing clean transport and adapting the model to national specifics.

KEYWORDS: development policy, electromobility, transport sector modeling, forecast, market

\section{Introduction}

In recent years, the gradual transition to electric transport use with the involvement of renewable energy sources (RES) has become a noticeable trend in the developing of the world's leading countries' economies. Many experts argue that the role of this type of transport in human activities will only increase over time. The reasons for this are the depletion of fossil fuels used in traditional car models and harmful emissions that enter the atmosphere due to the operation of vehicles on internal combustion engines. Fossil fuels' depletion causes energy prices to rise and gradually increases the cost of using traditional cars. In addition, the high environmental requirements for $\mathrm{CO}_{2}$ and other greenhouse gas emissions, which are applied in many countries around the world, add to the cost of operating traditional vehicles.

Today, the introduction and development of environmentally friendly electric cars based on renewable energy technologies is an example of a tandem capable of solving environmental (Kościółek and Biały 2018), economic (Drożdż et al. 2020) and energy problems (Gorova and Sheverdina 2015) as well as promoting the ecological modernization of national economies (Shkarupa et al. 2017). The use of RES in transport and other industries allows for the following: the strengthening of national energy and economic security (Dzwigoł et al. 2019), avoiding energy resources depletion (Prokopenko et al. 2018), preserving strategic energy reserves of states (Sotnyk 2016), moving to a low-carbon economy (Melnyk et al. 2019), improving air quality and, consequently, public health (Kubatko and Kubatko 2017, 2019).

Despite the significant electric transport advantages, both nationally and locally, the global electric vehicle market is in its infancy and is slowly expanding. Among the main obstacles to the more dynamic development of the sector, high prices for such vehicles due to the lack of their mass production, insufficient battery capacity, large amount of electricity consumed per km, as well as underdeveloped energy infrastructure for charging electric cars, which significantly limits the demand for these models, are present (Abhay Singh 2020). 
Essential savings on operating costs, ease and convenience of driving, environmental friendliness of electric vehicles attract many consumers and encourage them to give preference to electric models. The electric vehicles' sales are growing faster in developed countries with high incomes per capita, including the US, Germany, China, France, where households and businesses can afford such a "luxury" (Abhay Singh 2020). However, developing countries also need the deployment of environmentally friendly and energy efficient electric transport. Therefore, a detailed study of the determinants influencing the development of the transport sector can contribute to managing this process.

The purpose of the article is (1) to determine drivers for the deployment of the electric transport market on the example of the US using a multifactor linear regression model, and (2) to develop market forecasts considering identified factors as well as policy recommendations in the economic and energy security context.

\section{Literature Review}

The array of recent scientific publications on the electric vehicles' topic is quite large. It covers not only the economic and management aspects of electric car production and operation but also technical, environmental issues, etc. Today, electric transport includes passenger cars, city and intercity buses, trucks. However, the development of large vehicles is currently not as dynamic as personal car deployment since this sector requires considerable R\&D before broader market adoption can be achieved (ORNL and NREL 2019). Along with the technical aspects of electric vehicle production, chemical, physical, and other scientific research aimed at studying and creating efficient fuel cells - batteries are also present. One more issue to solve is management problems connected to the electricity market development since electricity serves as a fuel for electric motors. Given the diversity of research in the electric vehicle sector, the Scopus Analyze Tool was used to identify an array of scientific publications on the keywords "electric" and "vehicle" from 2000-2019. The results of the analysis are presented in Figure 1.

The figure shows that the vast majority of publications are devoted to the technical aspects of the electric vehicle sector, and only $2 \%$ are connected to economic issues. This is understandable since the development of the electric car market using economic mechanisms is impossible without the prior creation of a robust technical and production base. However, this ratio confirms the need to expand economic research in this field.

Over the past twenty years, there has been an increase in the number of articles related to electric transport from 728 in 2000 to 10,927 in 2019 (Fig. 2). The annual growth in the publications' volume was $16 \%$ on average (except for 2013 and 2015, when there was a slight decline in their number). This tendency indicates a high relevance of the electric vehicles' topic for the world scientific community. 


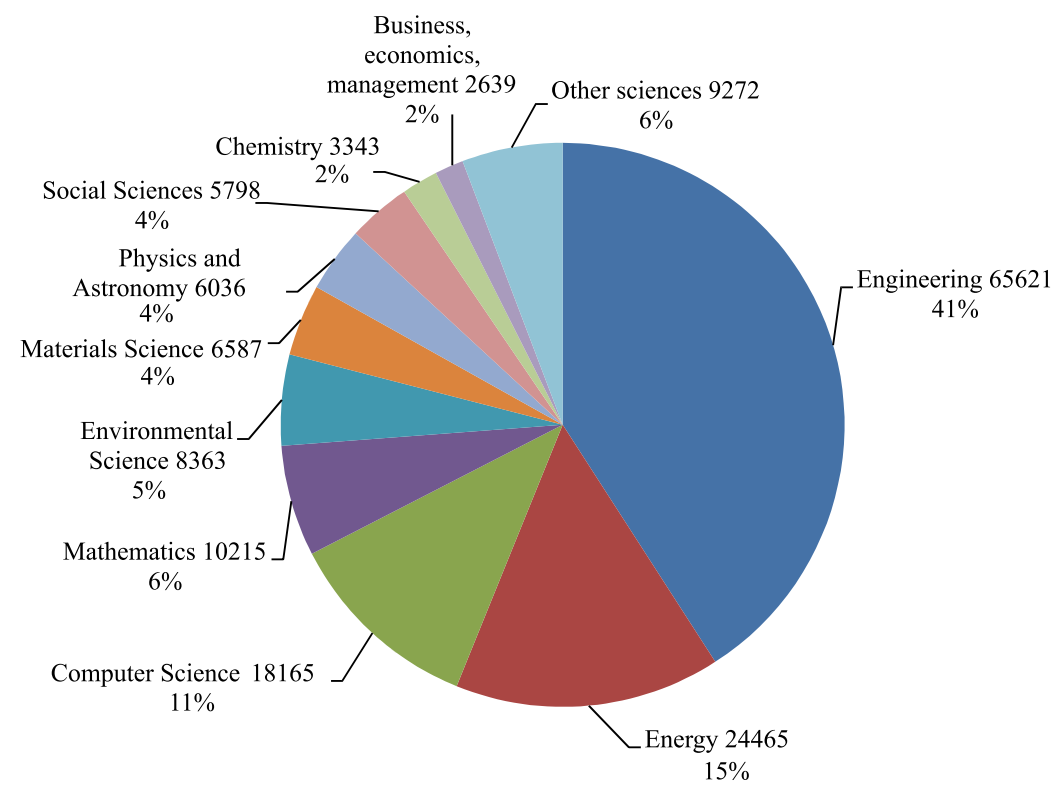

Fig. 1. Distribution of scientific research in the electric transport's field for 2000-2019 (according to the Scopus database)

Source: developed by the authors using the Scopus Analyze Tool

Rys. 1. Rozkład badań naukowych w dziedzinie transportu elektrycznego w latach 2000-2019

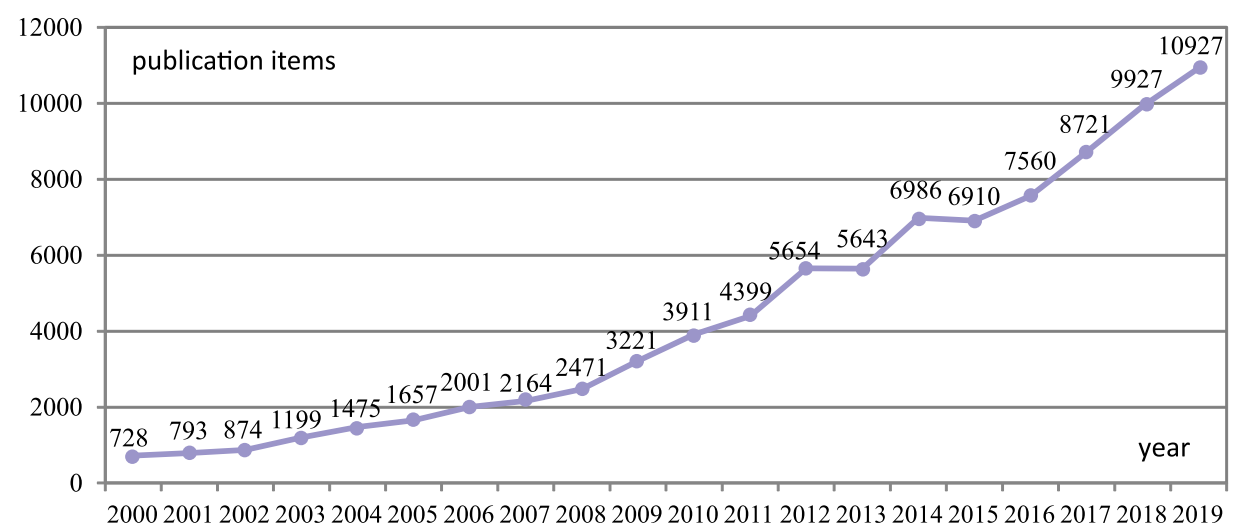

Fig. 2. Publications on electric transport issues in 2000-2019 (according to the Scopus database) Source: developed by the authors using the Scopus Analyze Tool

Rys. 2. Publikacje dotyczące zagadnień transportu elektrycznego w latach 2000-2019 
In terms of the number of articles on electric transport and its practical use, the leading countries are China, the US and Germany. The total amount of publications by authors from these three countries was 44,473 items in 2000-2019.

The researchers who deal with organizational, economic and management problems of the electric car market development are Kim J.D. (Kim 2019), Liu A., Zhao Y., Meng X., Zhang, Y. (Liu et al. 2020), Sang Y.-N., Bekhet H.A. (Sang and Bekhet 2015), Pandey A., Manocha S., Saini P. (Pandey et al. 2020), Rezvani Z., Jansson J., Bodin, J. (Rezvani et al. 2015), Tromaras A., Aggelakakis, A., Margaritis D. (Tromaras et al. 2017), Cahill E., Davies-Shawhyde J., Turrentine S.T. (Cahill et al. 2014), Girin V., Girin I. (Girin and Girin 2017), Gorova K., Sheverdina A. (Gorova and Sheverdina 2015), Gnann T., Plötz P., Kühn A., Wietschel M. (Gnann et al. 2015), Soltani-Sobh A., Heaslip K., Stevanovic A., Bosworth R., Radivojevic D. (Soltani-Sobh et al. 2017), Gnann T., Stephens T.S., Lin Z., Plötza P., Liu C., Brokate J. (Gnann et al. 2018) and others.

For example, based on data from the California Public Utilities Commission and San Diego Gas \& Electric (SDGE), Kim J.D. (Kim 2019) analyzes changes in consumption patterns caused by the proliferation of plug-in electric vehicles in households of the San Diego region in the US. The author concludes that there is a "twin demand peak" for electricity in the California residential area. The first one is due to the electric vehicles being charged by their owners in the evening and another one at midnight. Based on the identified trends, Kim J.D. proposes to balance power capacities regarding the future growth of the electric vehicles' share and to adjust the pricing policy of electric companies to the simultaneous development of power grids capable of withstanding additional loads.

Using a multi-criteria decision-making technique, Liu A., Zhao Y., Meng X. and Zhang Y. (Liu et al. 2020) determine the optimal location of charging stations for electric cars, which is an important prerequisite for the electric transport deployment. Their research is based on the method of Delphi's expert assessments and modern mathematical methods of decision-making modeling.

Sang Y.-N. and Bekhet H.A. (Sang and Bekhet 2015) study factors that influence the electric vehicle market development in Malaysia based on correlation analysis. The identified drivers are the level of consumers' environmental concern, their knowledge of the electric vehicles' advantages, psychological benefits, and demographic characteristics of the population. Based on the obtained results, the authors formed marketing strategies for players in the electric car market in Malaysia.

Pandey A., Manocha S. and Saini P. (Pandey et al. 2020) explore the possibilities of developing the electric vehicle market in India, considering the barriers and benefits that will accompany the full transition to electric transport use. The authors studied both the technical aspects of this process (charging methods, charging stations and their network, electric car models, etc.) and management ones (governmental policy for market development, environmental and economic effects of the deployment of the electric vehicles, etc.).

Rezvani Z., Jansson J. and Bodin J. (Rezvani et al. 2015) analyze comprehensive drivers for and barriers against the consumer adoption of plug-in electric vehicles. It helps to better 
understand consumer intentions and develop effective economic policies to expand the electric car market. The authors conclude that the high electric vehicles' cost is a major barrier to their purchase and use. Instead, the expected moral satisfaction and environmental awareness of consumers positively affect decisions about the purchase and use of electric transport.

Tromaras A., Aggelakakis A. and Margaritis D. (Tromaras et al. 2017) explore the contribution of car dealers in the electric vehicle market up-take on the example of Greece. Based on surveys of two Greek electric car distributors, the authors point to the critical influence of vehicle sellers on their customers' decisions while informing customers about the benefits and disadvantages of electric models. General recommendations for increasing electric car sales in the country are state assistance to improve the training of sellers, dissemination of information to the public about the gains of using electric vehicles, building an extended network of charging stations, etc.

Cahill E., Davies-Shawhyde J. and Turrentine S.T. (Cahill et al. 2014) assess the car dealers' impact on electric vehicle sales in California in the US. They conclude that lower profits from electric car sales often lead sellers to persuade customers to buy traditional models. Therefore, the strengthening of environmental requirements for vehicles, preferential tax policy for electric transport manufacturers, and introduction of state programs for partial compensation of the electric car cost for buyers along with establishing the terms of vehicle's mandatory use will contribute to the environmentally friendly transport segment development.

Girin V. and Girin I. (Girin and Girin 2017) study the Ukrainian electric car market and identify problems of its deployment to form a concept for their solution. They note that the market is growing, but significant barriers to its expansion are the limited ability to charge an electric vehicle at home and the underdeveloped national network of charging stations. In addition, Gorova K. and Sheverdina A. (Gorova and Sheverdina 2015) point to the high cost of purchasing an electric car, the lack of a charging stations' network and an insufficient number of specialists in electric transport maintenance in Ukraine. The authors identify the advantages of electric vehicles for owners as the opportunity to save on fuel and for the state as a decline in environmental pollution, thereby justifying the need for further government incentives for market development.

Gnann T., Plötz P., Kühn A. and Wietschel M. (Gnann et al. 2015) study the evolution of the electric vehicle market in Germany until 2020, pointing to essential growth rates of the sector. They testify that crucial factors influencing the deployment of the German market are energy prices, state compensation for the electric car prices, and flexible credit policy. At the same time, the authors emphasize the high uncertainty of market evolution and conclude that state policy in this area must be dynamically adapted to respond to the changing market conditions.

Due to the analysis of publications, the main determinants influencing the world's electric car market deployment are technical, economic (cost of vehicles, availability of charging stations, savings on operating costs) and environmental (consumers' environmental awareness, opportunities to reduce pollution, etc.). Many scientific papers study micro-level factors, while the researchers often miss macroeconomic drivers. However, the electric transport potential is quite strong to provide the economic and energy security of national economies. Therefore, it is expedient to do research that allows to identify macro-level factors affecting the development of the electric car market and contribute to the growth of national security. 


\section{Methods and Methodology}

Given the importance of the electric transport sector expansion for environmental, economic and energy security of countries and the high relevance of this research area, a methodology has been developed for studying the electric car market on the example of the US. It is based on the construction of a multifactor model, which reflects the market size dependence on a number of macroeconomic drivers and provides the forecasts of the market deployment. The research was carried out by performing several stages according to the algorithm shown in Figure 3.

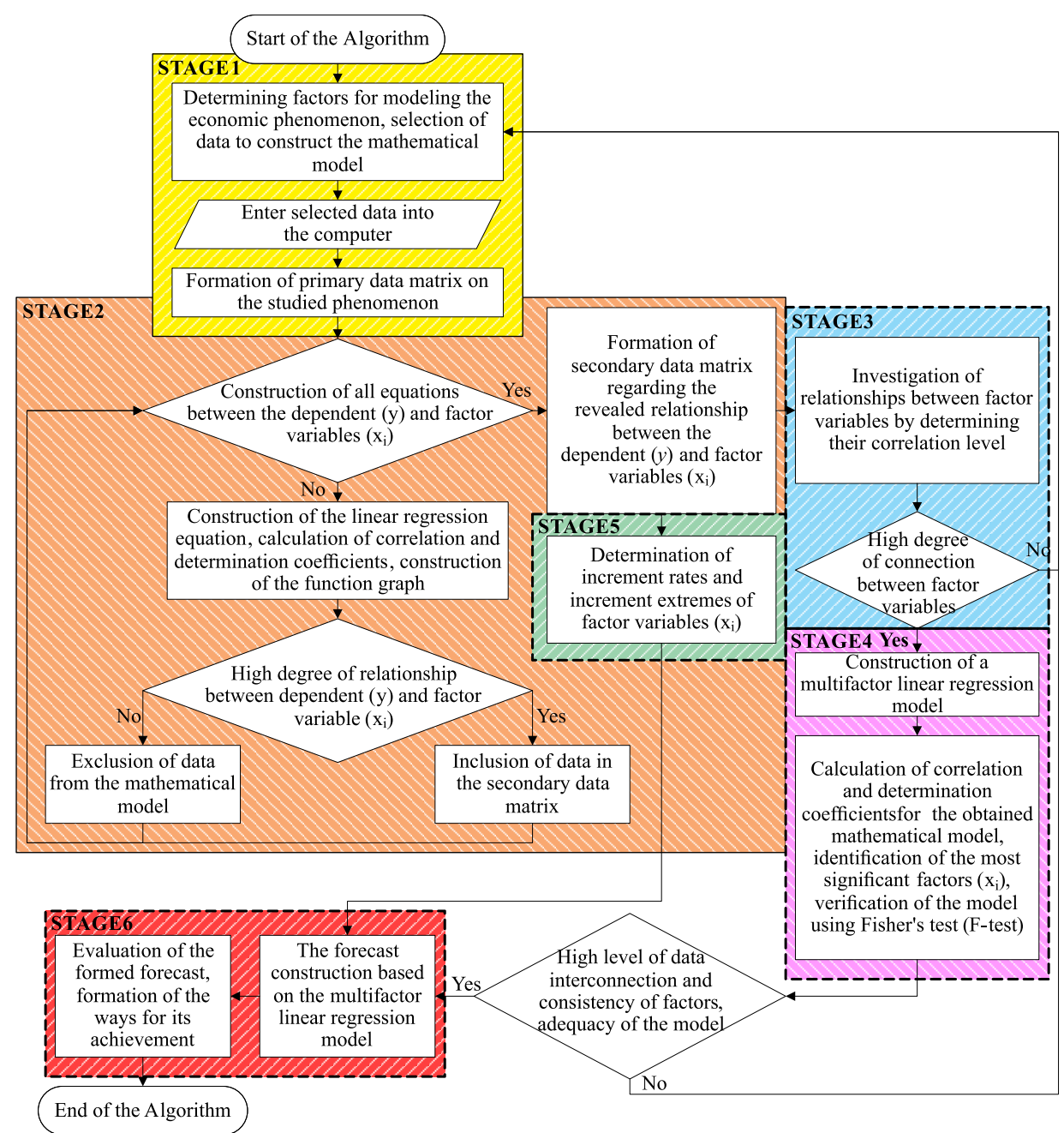

Fig. 3. The research algorithm of constructing the mathematical model and the forecast for the US electric car market Source: developed by the authors 
The constructed econometric models describe the relationship between the factor and dependent variables using the linear regression method (Kassambara 2018). The latter is widely used by scientists, including for the study of renewable energy (Yevdokimov et al. 2018) and green investment development (Lyeonov et al. 2019), energy security (Vasylyeva et al. 2014), energy assessment of building design (Hygh et al. 2012), prediction of residential energy consumption (Fumo and Rafe Biswas 2015), knowledge transfer on the energy market (Miśkiewicz 2018), market (Dumirescu et al. 2012) and socio-economic processes (Bilan et al. 2019) etc.

Firstly, a correlation-regression analysis was performed to identify the degree of factors' influence on the dependent indicator. It allowed determining the primary and secondary factors of influence to be determined. At stage 2, it was investigated the pairwise correlation between the dependent variable $y$ and each of the factors $x_{1}, x_{2}, x_{3}, x_{4}$ was investigated. Using the least squares method, there formed four simple linear regression equations, which estimated with the help of the correlation $(r)$ and determination $\left(R^{2}\right)$ coefficients (Kennedy 2008). Then graphs with trend lines were built and studied with the data connections. A correlation coefficient was also applied to determine the relationships between factor variables at stage 3 . At stage 4 , a multifactor model of linear regression was built and verified by using a multiple correlation coefficient (Kennedy 2008). The "Data Analysis" functionality of Microsoft Excel was applied to models' development and their graphical interpretation, definition and analysis of correlation and determination coefficients as well as verification of the constructed models. At stage 5, the method of averages and determination of the extremes of interannual deviations of the indicators' values was used to forecast the electric car market size (Kennedy 2008).

\section{Results and Discussion}

Due to performing the research algorithm, the findings are as follows:

Stage 1. Calculations at this stage were performed on the example of the US data. The main reason for choosing this country for research is that the US is one of the innovative leaders in the manufacture and use of electric vehicles. In addition, it leads the way in the number of scientific studies in the field. Its national economy is characterized by stable development, which is important for obtaining adequate econometric models. Moreover, the robust statistical data is available for this country. The obtained simulation results can be adapted for use in other national economies regarding their specifics, e.g., stage of economic development, population, current size of the electric car market, energy infrastructure and use etc.

While modeling the electric car market size in the US, there were chosen four hypothetically interdependent factors, namely:

1) economic $\left(x_{1}\right)$, which is presented by the gross domestic product (GDP) indicator;

2) energy $\left(x_{2}\right)$, which is represented by the level of electricity use in the country;

3) socio-economic $\left(x_{3}\right)$, which is expressed in the level of a household income in the country; 
4) environmental $\left(x_{4}\right)$, which is estimated through the level of $\mathrm{CO}_{2}$ emissions into the atmosphere.

These determinants were chosen given their anticipating impact on the electric vehicle market deployment and the relationship with energy security, namely:

$\checkmark$ economic and socio-economic factors are indicators of wealth, economic maturity and purchasing power of the US population. They may significantly affect the consumer's personal choice of a car model;

$\downarrow$ an energy driver reflects the influence of the fuel component used to move electric vehicles;

$\checkmark$ an environmental factor determines changes in the harmful emissions' level into the atmosphere due to introducing environmentally friendly electric cars. This may influence the transport market development and state policy in the sector. For example, in the UK in 2019, the lifetime emissions per kilometer of driving a Nissan Leaf electric vehicle were about three times lower than for the average conventional car (Hausfather 2019). Wietschel M. Kühnbach M. and Rüdiger D. (Wietschel et al. 2019) found that emissions from electric cars were up to $43 \%$ lower than from diesel vehicles.

For calculations and the construction of econometric models, the relevant US statistics from the open databases of the World Bank, the US Bureau of Transportation Statistics, the US Energy Information Administration and the US Census Bureau were used. The period of the study was chosen from 2011-2018 since these years demonstrate the highest pace of the electric car market development in the country. Y2019 was not included in the calculations due to the lack of complete statistical data. The primary data matrix used to construct the regression models is given in Table 1.

TABLE 1. Primary data matrix for constructing linear regression models

TABELA 1. Podstawowa macierz danych do budowy modeli regresji liniowej

\begin{tabular}{|c|c|c|c|c|c|}
\hline Year & $\begin{array}{c}\text { Number of electric } \\
\text { vehicles sold }(y), \text { units }\end{array}$ & $\begin{array}{c}\text { GDP }\left(x_{1}\right), \\
\text { bln USD }\end{array}$ & $\begin{array}{c}\text { Electricity use }\left(x_{2}\right), \\
\text { bln kWh }\end{array}$ & $\begin{array}{c}\text { Income per } \\
\text { household }\left(x_{3}\right), \text { USD }\end{array}$ & $\begin{array}{c}\mathrm{CO}_{2} \text { emissions }\left(x_{4}\right), \\
\text { mln metric tons }\end{array}$ \\
\hline 2011 & 10,100 & 15,543 & 3,883 & 56,006 & 5,446 \\
\hline 2012 & 14,600 & 16,197 & 3,832 & 55,900 & 5,229 \\
\hline 2013 & 48,100 & 16,785 & 3,868 & 57,856 & 5,356 \\
\hline 2014 & 63,500 & 17,522 & 3,903 & 56,969 & 5,413 \\
\hline 2015 & 71,100 & 18,219 & 3,900 & 59,901 & 5,263 \\
\hline 2016 & 86,700 & 18,707 & 3,902 & 61,779 & 5,170 \\
\hline 2017 & 104,400 & 19,485 & 3,864 & 62,626 & 5,131 \\
\hline 2018 & 238,800 & 20,544 & 4,003 & 63,179 & 5,281 \\
\hline & \multicolumn{7}{|c|}{ Secondary data matrix } \\
\hline
\end{tabular}

Source: developed by the authors based on data (Bureau 2020; Census 2020; U.S. Energy 2020; World Bank 2020). 
Stage 2. At this stage, four paired linear regression equations have been constructed, which reflect the correlation between dependent and factor variables. The calculation results are given in Table 2.

A graphical illustration of the revealed dependencies is given in Figure 4.

TABLE 2. The results of the linear regression equations construction

TABELA 2. Wyniki równań regresji liniowej

\begin{tabular}{|c|c|c|c|}
\hline Dependence & $\begin{array}{c}\text { Linear regression } \\
\text { equation }\end{array}$ & $\begin{array}{c}\text { Correlation coefficient } \\
(r)\end{array}$ & $\begin{array}{c}\text { Determination coefficient } \\
\left(R^{2}\right)\end{array}$ \\
\hline$y\left(x_{1}\right)$ & $y=-613342+38.8 x_{1}$ & 0.91 & 0.83 \\
\hline$y\left(x_{2}\right)$ & $y=-4806154+1254.68 x_{2}$ & 0.87 & 0.76 \\
\hline$y\left(x_{3}\right)$ & $y=-1100820+19.9 x_{3}$ & 0.83 & 0.68 \\
\hline$y\left(x_{4}\right)$ & $y=1097821-192.6 x_{4}$ & 0.29 & 0.09 \\
\hline
\end{tabular}

Source: developed by the authors using the "Data Analysis" functionality of Microsoft Excel.
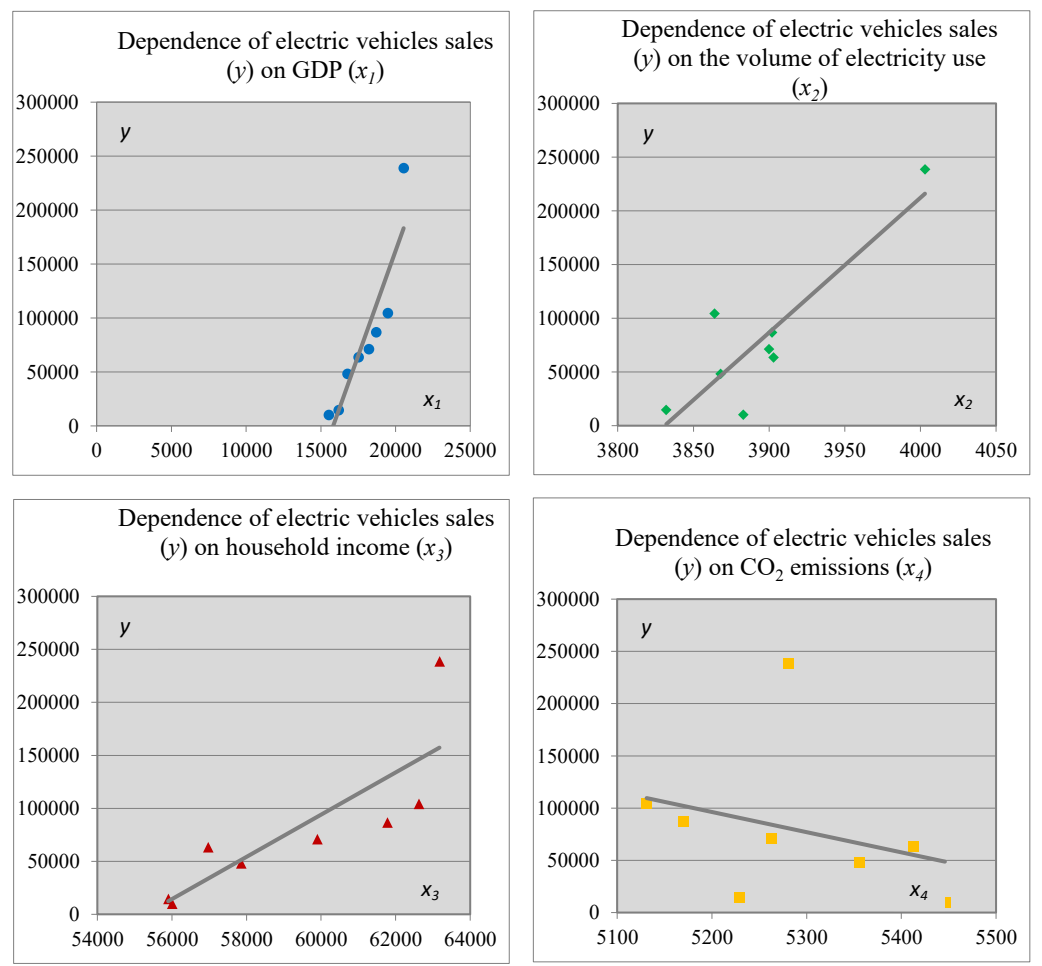

Fig. 4. Graphical interpretation of the relationship between the dependent variable $y$ and the factors $x_{1}, x_{2}, x_{3}, x_{4}$ Source: developed by the authors using Microsoft Excel

Rys. 4. Graficzna interpretacja zależności między zmienną zależną $y$ a czynnikami $x_{1}, x_{2}, x_{3}, x_{4}$ 
Analysis of the results shows the following:

1. We found and verified statistically significant relationships between the factors $x_{1}, x_{2}, x_{3}$ and the dependent variable $y$.

2. For the factor $x_{4}$, the relationship between the environmental driver and $y$ is weak, making it impossible to use this factor to build an adequate multifactor linear regression model. In general, increasing number of electric cars may lead to $\mathrm{CO}_{2}$ emission reduction except for the rebound effect. However, the small share of electric vehicles compared to the traditional ones, which are the main carbon dioxide generators, can explain the statistical insignificance of $y\left(x_{4}\right)$ for the US market. Given the information above, for further research a secondary data matrix was formed by excluding the environmental factor $\left(x_{4}\right)$ from consideration, which was taken into account in the primary data matrix (see Table 1).

Stage 3. The factors selected at the previous stage are directly and closely related to the dependent variable. Therefore, they can be used to construct a multifactor model. Based on the obtained results, the correlations between these drivers have been studied. The correlation matrix is given in Table 3 .

TABLE 3. Correlation matrix of relationships between $y$ and $x_{1}, x_{2}, x_{3}, x_{4}$

TABELA 3. Macierz korelacji między $y$ a $x_{1}, x_{2}, x_{3}, x_{4}$

\begin{tabular}{|l|c|c|c|c|}
\hline \multicolumn{1}{|c|}{ Indicator } & $\begin{array}{c}\text { Number of electric } \\
\text { vehicles sold }(y)\end{array}$ & GDP $\left(x_{1}\right)$ & $\begin{array}{c}\text { Electricity } \\
\text { use }\left(x_{2}\right)\end{array}$ & $\begin{array}{c}\text { Income per } \\
\text { household }\left(x_{3}\right)\end{array}$ \\
\hline Number of electric vehicles sold $(y)$ & 1.00 & - & - & - \\
\hline GDP $\left(x_{1}\right)$ & 0.91 & 1.00 & - & - \\
\hline Electricity use $\left(x_{2}\right)$ & 0.87 & 0.68 & 1.00 & - \\
\hline Income per household $\left(x_{3}\right)$ & 0.83 & 0.95 & 0.58 & 1.00 \\
\hline
\end{tabular}

Source: developed by the authors using the "Data Analysis" functionality of Microsoft Excel.

According to the Chaddock scale (Kennedy 2008), the data demonstrate high interconnectedness. The relationship between electricity use and household income is less close than other links, but it is sufficient to consider when constructing a multifactor linear regression model.

Stage 4. Based on the secondary data matrix (see Table 1), a multifactor linear regression model that reflects the dependence of $y$ on $x_{1}, x_{2}$, and $x_{3}$ have been constructed:

$$
y=-2840344+30.22 x_{1}+653.30 x_{2}-2.77 x_{3}
$$

The calculations show that the multiple correlation coefficient is equal to 0.97 , while the coefficient of determination is 0.94 . They indicate a high level of data interconnection and 
consistency of factors in the model. The adequacy of the obtained model was checked by using F-Test $(F)$. While doing this, the calculation criterion $F$ was compared with its critical value: $F_{\text {cal }}=0.04, F_{\text {critical }}=6.59$, herewith $F_{\text {critical }}$ was taken for $f_{1}=3$ and $f_{2}=4$ (Kennedy 2008).

Since $F_{\text {cal }}<F_{\text {critical }}$, the constructed regression model is adequate. Among other factors, the driver $x_{2}$ (electricity use) demonstrates the most considerable positive influence on the change in the number of electric cars sold. This can be explained by the impact of the country's energy system development on progress in the transport sector, as electricity is the fuel for electric vehicles. In addition, the electricity demand increase may lead to the growth of energy capacities. Since electric cars can charge in the evening and midnight hours, it can contribute to balancing electricity capacities without involving the construction of the new ones (Todd and Thorstensen 2013). Therefore, rising electricity demand may encourage increasing the number of sold electric cars. Also, GDP growth positively affects the electric car market size, since GDP is an indicator of the population purchasing power, and, to some extent, people's consumer and technological knowledge and awareness. Surprisingly, the level of household income has a negative impact on the electric vehicle market. This means that without providing additional information by car dealers, the population with higher incomes will be more likely to buy traditional car models than electric ones, whose operation is unfamiliar to ordinary consumers.

The factors' elasticities are $6.78,31.93$, and -2.06 respectively. Therefore, if one of the drivers changes by $1 \%$, other things being equal, the dependent variable $y$ will increase or decrease on average by a corresponding percentage.

Stage 5. The results of multifactor modeling have been used to develop a forecast for electric vehicle sales in the US in the coming years. The increment extremes and the average values of increments for $x_{1}, x_{2}, x_{3}$ calculated based on Table 1 are presented in Table 4 .

TABLE 4. Maximum, minimum, and average growth deviations of factor variables $x_{1}, x_{2}, x_{3}$ for developing the electric car market forecast

TABELA 4. Maksymalne, minimalne i średnie odchylenia wzrostu zmiennych $x_{1}, x_{2}, x_{3}$ dla opracowania prognozy rynku samochodów elektrycznych

\begin{tabular}{|l|c|c|c|}
\hline \multicolumn{1}{|c|}{ Indicator } & GDP $\left(x_{1}\right)[\%]$ & Electricity use $\left(x_{2}\right)[\%]$ & Income per household $\left(x_{3}\right)[\%]$ \\
\hline Maximum increase/decrease & 5.4 & 3.6 & 5.1 \\
\hline Average increase/decrease & 4.0 & 0.4 & 1.8 \\
\hline Minimum increase/decrease & 2.7 & -1.3 & -1.5 \\
\hline
\end{tabular}

Source: calculated by the authors based on the data (Bureau 2020; Census 2020; U.S. Energy 2020; World Bank 2020).

Stage 6. Applying the data from Table 4 and the mathematical model obtained at stage 4, three scenarios (optimistic, optimal and pessimistic) of the US electric car market deployment in 2019-2023 have been developed. The data for each scenario was calculated, considering the 
static set of indicators from the secondary data matrix of Table 1 . The values for each subsequent year were obtained regarding the previous period. The forecast results are shown in Figure 5.

According to the optimal scenario, which assumes the average growth rate of factor indicators $x_{1}, x_{2}, x_{3}$ during 2019-2023, the number of electric cars sold will increase by $64 \%$ (from the level of 2018) in five years, which will help reduce $\mathrm{CO}_{2}$ emissions and strengthen the US energy security. The optimistic scenario is ambiguous and questionable, as it assumes extreme growth rates for all three factor indicators over five years. However, in the case of such a scenario, the US electric car market will increase by 3.6 times compared to its actual size in 2018 (238,800 items). In the five-year perspective, a pessimistic scenario with an increase in $x_{1}$ and a decline in $x_{2}$ and $x_{3}$ will lead to market stagnation and a reduction in its size by 82,215 cars in 2023 or $34.4 \%$ of the 2018 level. The stagnation consequences may be an increase in fossil fuels used by traditional vehicles, and, therefore, changes in the structure of the country's fuel and energy balance towards the consumption of oil cracked products, increasing $\mathrm{CO}_{2}$ emissions, which will negatively affect energy security and environmental quality.

Overall, to strengthen national energy security by developing the electric car market in the US as well as to implement at least the optimal scenario, ensuring GDP growth. Besides, it is essential to create conditions for rising electricity use and household incomes while convincing people to get the advantage of an electric car when deciding to buy a new vehicle are necessary.

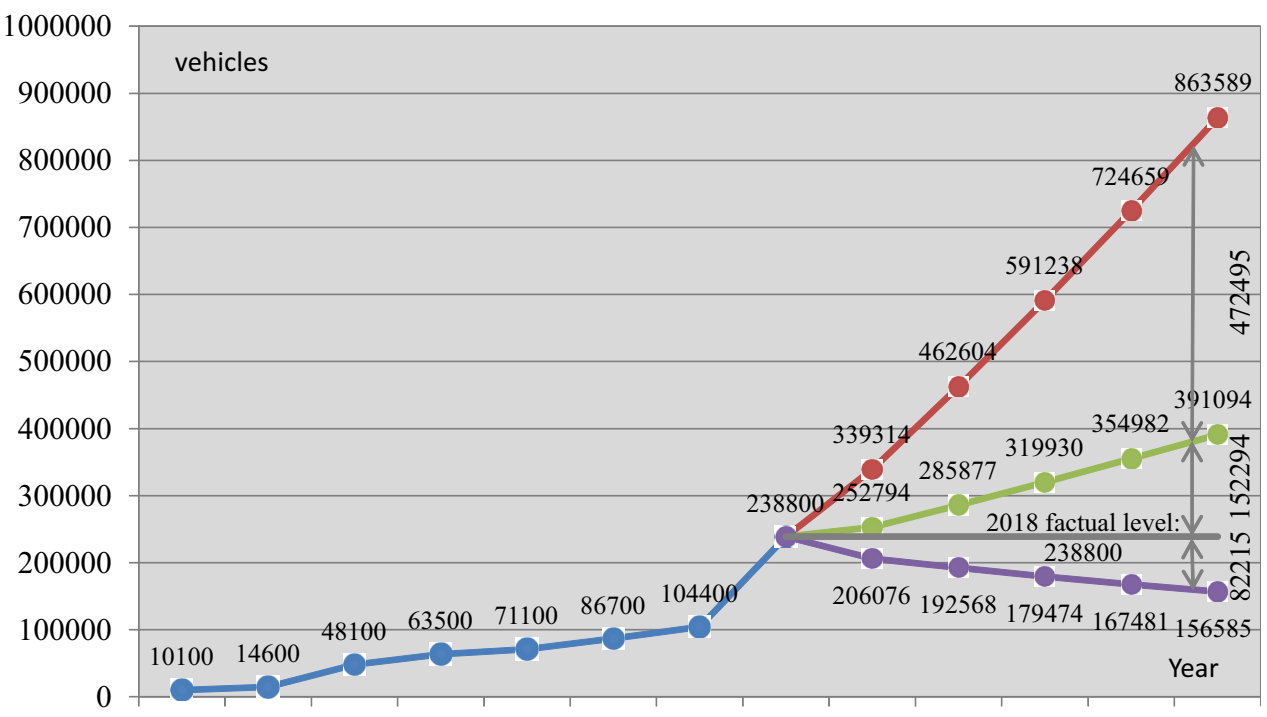

$\begin{array}{lllllllllllll}2011 & 2012 & 2013 & 2014 & 2015 & 2016 & 2017 & 2018 & 2019 & 2020 & 2021 & 2022 & 2023\end{array}$

Optimal scenario of the market development $\quad$ - Optimistic scenario of the market development

Fig. 5. Forecast scenarios for the US electric car market development in 2019-2023, vehicles Source: developed by the authors

Rys. 5. Scenariusze prognostyczne rozwoju rynku samochodów elektrycznych w USA w latach 2019-2023, liczba pojazdów 


\section{Conclusions}

The constructed multifactor regression model demonstrates the dependence of the US electric vehicle market size on economic (GDP), socio-economic (household income) and energy (electricity use) determinants. The latter has the most significant positive impact on market development as electricity is the fuel for electric transport. GDP growth got a second place among the market deployment drivers. Surprisingly, the increase in household income negatively affects electric car sales due to inertia and the lack of public awareness of the electric vehicle operating benefits. Having enough money to buy a new car, car dealers' clients are still choosing timetested traditional models with internal combustion engines, despite their higher operating costs compared to electric vehicles and the harmful environmental effects.

The implementation of the developed optimal and optimistic forecasts of the US electric transport market expansion requires ensuring the growth of economic and energy factors as well as the transformation of the socio-economic driver (household income) into a positive one. The electric car market deployment can significantly contribute to strengthening the country's energy security by attracting RES to electricity generation and increasing environmental quality by reducing $\mathrm{CO}_{2}$ emissions. Therefore, the policy recommendations to improve macroeconomic factors' management in the transport sector are as follows:

$\checkmark$ to ensure further stable growth of the country's GDP, taking the necessary measures to eliminate the negative impact of the COVID-19 pandemic on this indicator; to provide the state support for the development of mass production of environmentally friendly and energy efficient electric vehicles;

$\checkmark$ to stimulate the transition of households and enterprises to the generation and use of electricity from RES; to motivate business agents at the state level to invest in the energy infrastructure development for recharging electric cars;

$\checkmark$ to ensure further growth of household incomes while informing the public about the environmental, economic and technical benefits of electric transport, including conducting state information campaigns, supporting the training of car dealers' employees on the electric transport peculiarities, etc. It will convince more Americans to choose an electric car instead of buying a traditional model with a gasoline or diesel engine. Thus, household income will turn from a negative to a positive driver of market development. The alternative way is to introduce discounts and partial government compensation to the electric car prices, provide a tax credit to new owners of environmentally friendly vehicles, etc., thus reducing the actual consumer cost for purchasing electric cars;

$\checkmark$ despite the weak link between the environmental factor $\left(\mathrm{CO}_{2}\right.$ emissions) and the electric transport market expansion due to the small share of the latter, the state should continue to strengthen ecological standards for car fuel and vehicles themselves, implementing a gradual transition to the use of electric cars only.

Overall, the introduction of the proposed recommendations in economic practice will allow combining electric transport technologies with renewable energy and achieve positive changes 
in the country's energy balance by reducing the share of fossil fuels, moving to a low-carbon economy without compromising economic development and welfare. The results of the study can be used to improve public policy in the US transport and energy sectors, as well as in other countries to strengthen the energy independence of states by developing clean transport and adapting the model to national specifics.

The paper has been supported by the Ministry of Education and Science of Ukraine under the research projects "Innovative management of energy-efficient and resource-saving technologies in Ukraine" (No. 0118U003571), "System model of efficiency management and forecasting of electricity use" (No. 0118U003583) and "Development of fundamental principles of reproduction mechanism of the social and economic development during the Third Industrial Revolution" (No. 0118U003578).

\section{References}

Abhay, Singh 2020. Electric vehicle market. [Online] https://www.alliedmarketresearch.com/electric-vehicle-market [Accessed: 2020-09-4].

Bilan et al. 2019 - Bilan, Y., Vasilyeva, T., Lyeonov, S. and Bagmet, K. 2019. Institutional complementarity for social and economic development. Business: Theory and Practice 20, pp. 103-115, DOI: 10.3846/BTP.2019.10.

Bureau of Transportation Statistics 2020. United States Department of Transportation. [Online] https:// www.bts.gov/content/gasoline-hybrid-and-electric-vehicle-sales [Accessed: 2020-09-4].

Cahill et al. 2014 - CAhill, E., Davies-Shawhyde, J. and Turrentine, S.T. 2014. New car dealers and retail innovation in California's plug-in electric vehicle market. Institute of Transportation Studies, University of California, Davis, Working Paper UCD-ITS-WP-14-04.

Census Bureau of USA 2020. [Online] https://www.census.gov/data/tables/time-series/demo/income-poverty/historical-income-households.html [Accessed: 2020-09-4].

DrożDż et al. 2020 - DrożDż, W., Szczerba, P. and KruszyŃSKI, D. 2020. Issues related to the development of electromobility from the point of view of Polish utilities. Polityka Energetyczna - Energy Policy Journal 23(1), pp. 49-64; DOI: 10.33223/epj/119074.

Dumirescu et al. 2012 - Dumirescu, L., Stanciu, O., Tichindelean, M. and Vinerean, S. 2012. The use of regression analysis in marketing research. Studies in Business and Economics 7(2), pp. 94-109.

Dzwigol et al. 2019 - Dzwigol, H., Dzwigol-Barosz, M., Zhyvko, Z., Miskiewicz, R. and Pushak, H. 2019. Evaluation of the Energy Security as a Component of National Security of the Country. Journal of Security and Sustainability 8(3), pp. 307-317; DOI: 10.9770/jssi.2019.8.3(2).

Fumo, N. and RAFE BISWAS, M.A. 2015. Regression analysis for prediction of residential energy consumption. Renewable and Sustainable Energy Reviews 47, pp. 332-43; DOI: 10.1016/j.rser.2015.03.035.

GIRIN, V. and GiRIN, I. 2017. The current state of electric vehicles and its prospects in Ukraine. Mining Bulletin 102, pp. 21-25.

Gnann et al. 2015 - Gnann, T., Plötz, P., KüHn, A. and Wietschel, M. 2015. Modelling market diffusion of electric vehicles with real world driving data - German market and policy options. Transportation Research Part A: Policy and Practice 77, pp. 95-112; DOI: 10.1016/j.tra.2015.04.001.

Gnann et al. 2018 - Gnann, T., Stephens, T.S., Lin, Z., Plötza, P., Liu, C. and Brokate, J. 2018. What drives the market for plug-in electric vehicles? - A review of international PEV market diffusion models. Renewable and Sustainable Energy Reviews 93, pp. 158-164; DOI: 10.1016/j.rser.2018.03.055. 
Gorova, K. and Sheverdina, A. 2015. The actuality of electric cars usage in Ukraine. Problems and prospects of entrepreneurship development 3(1), pp. 105-107.

Hausfather, Z. 2019. Factcheck: How electric vehicles help to tackle climate change. [Online] https:// www.carbonbrief.org/factcheck-how-electric-vehicles-help-to-tackle-climate-change [Accessed: 2020-09-24].

Hygh et al. 2012 - Hygh, J.S., DeCarolis, J.F., Hill, D.B. and Ranji Ranjithan, S. 2012. Multivariate regression as an energy assessment tool in early building design. Building and Environment 57, pp. 165-75; DOI: 10.1016/j.buildenv.2012.04.021.

Kassambara, A. 2018. Simple linear regression in R. [Online] http://www.sthda.com/english/articles/ 40-regression-analysis/167-simple-linear-regression-in-r/ [Accessed: 2020-09-4].

KenNEDy, P. 2008. A Guide to Econometrics, $6^{\text {th }}$ Edition. Wiley-Blackwell, Hoboken, N. Jersey.

KIM, J.D. 2019. Insights into residential EV charging behavior using energy meter data. Energy Policy 129, pp. 610-618; DOI: 10.1016/j.enpol.2019.02.049.

KoŚCIÓŁeK, M. and BiAŁY, R. 2018. The comparison of structure of fuel consumption structure in land transport in Poland and selected European countries (Porównanie struktur zużycia paliw w transporcie

lądowym w Polsce oraz wybranych krajach europejskich). Polityka Energetyczna - Energy Policy Journal 21(1), pp.117-127 (in Polish).

Kuватко, O. and Kuватко, O. 2017. Economic estimations of pollution related cancer and nerves morbidity. International Journal of Ecology \& Development 32(1), pp. 33-43.

KuвAтко, O. and Kuватко, O. 2019. Economic estimations of air pollution health nexus. Environment, Development and Sustainability: A Multidisciplinary Approach to the Theory and Practice of Sustainable Development, Springer 21(3), pp. 1507-1517; DOI: 10.1007/s10668-018-0252-6.

Lyeonov et al. 2019 - Lyeonov, S., Pimonenko, T., Bilan, Y., Štreimikiene, D. and Mentel, G. 2019. Assessment of green investments' impact on sustainable development: Linking gross domestic product per capita, greenhouse gas emissions and renewable energy. Energies 12(20), pp. 3891; DOI: 10.3390/ en12203891.

LiU et al. 2020 - Liu, A., Zhao, Y., Meng, X. and Zhang, Y. 2020. A three-phase fuzzy multi-criteria decision model for charging station location of the sharing electric vehicle. International Journal of Production Economics 225, pp. 107572; DOI: 10.1016/j.ijpe.2019.107572.

Melnyk et al. 2019 - Melnyk, L., Kubatko, O., Dehtyarova, I., Matsenko, O. and Rozhko, O. 2019. The effect of industrial revolutions on the transformation of social and economic systems. Problems and Perspectives in Management 17(4), pp. 381-391; DOI: 10.21511/ppm.17(4).2019.31.

Miśkiewicz, R. 2018. The importance of knowledge transfer on the energy market. Polityka Energetyczna - Energy Policy Journal 21(2), pp. 49-62; DOI: 10.24425\%2F122774.

ORNL and NREL 2019 - Oak Ridge National Laboratory (ORNL) and National Renewable Energy Laboratory (NREL) 2019. Medium- and heavy-duty vehicle electrification. An assessment of technology and knowledge gaps. ORNL/SPR-2020/7 [Online] https://info.ornl.gov/sites/publications/Files/ Pub136575.pdf [Accessed: 2020-09-24].

Pandey et al. 2020 - PANDEY, A., MANOChA, S. and SAINI, P. 2020. A study on an automobile revolution and future of electric cars in India. International Journal of Management 11(3), pp. 107-113.

Prokopenko et al. 2018 - Prokopenko, O., OMelyanenko, V., and Klisinski, J. 2018. Innovation policy development conceptual framework for national resource security providing. Journal of Environmental Management and Tourism 9(5), pp. 1099-1107; DOI: 10.14505//jemt.v9.5(29).23.

REZvANi et al. 2015 - REZvANI, Z., JANSSON, J. and Bodin, J. 2015. Advances in consumer electric vehicle adoption research: A review and research agenda. Transportation Research Part D: Transport and Environment 34, pp. 122-136; DOI: 10.1016/j.trd.2014.10.010. 
SANG, Y.-N. and BeKHET, H.A. 2015. Exploring factors influencing electric vehicle usage intention: an empirical study in Malaysia. International Journal of Business and Society 16(1), pp. 57-74; DOI: 10.33736/ijbs.554.2015.

ShKarupa et al. 2017 - ShKarupa, O., KarintSEva, O. and Zhukova, T. 2017. Ecological modernization of the transport system in Sumy for green growth of economics. International Journal of Ecology and Development 32(3), pp. 75-85.

Soltani-Sobh et al. 2017 - Soltani-Sobh, A., Heaslip, K., Stevanovic, A., Bosworth, R. and RadivojeVIC, D. 2017. Analysis of the electric vehicles adoption over the United States. Transportation Research Procedia 22, pp. 203-212; DOI: 10.1016/j.trpro.2017.03.027.

SOTNYK, I. 2016. Energy efficiency of Ukrainian economy: problems and prospects of achievement with the help of ESCOs. Actual Problems of Economics 1, pp. 192-199.

Todd, J. and Thorstensen, L. 2013. Creating the clean energy economy. Analysis of the electric vehicle industry. International Economic Development Council [Online] https://www.iedconline.org/clientuploads/Downloads/edrp/IEDC_Electric_Vehicle_Industry.pdf [Accessed: 2020-09-24].

Tromaras et al. 2017 - Tromaras, A., AgGelakakis, A. and Margaritis, D. 2017. Car dealerships and their role in electric vehicles' market penetration - a Greek market case study. Transportation Research Procedia 24, pp. 259-266; DOI: 10.1016/j.trpro.2017.05.116.

U.S. Energy Information Administration 2020. Total energy. [Online] https://www.eia.gov/totalenergy/ data/browser/index.php?tbl=T11.01\#/?f=A\&start=2011\&end=2017\&charted=1-13 [Accessed: 202009-4].

VAsylyeVA, T.A. and Pryymenko, S.A. 2014. Environmental economic assessment of energy resources in the context of Ukraine's energy security. Actual Problems of Economics 160(1), pp. 252-260.

WiEtsChel et al. 2019 - WietsChel, M., KÜHNBACH, M. and RüDigER, D. 2019. Die aktuelle treibhausgasemissionsbilanz von elektrofahrzeugen in Deutschland. Working Paper Sustainability and Innovation No. S 02/2019 [Online] https://www.isi.fraunhofer.de/content/dam/isi/dokumente/sustainability-innovation/2019/WP02-2019_Treibhausgasemissionsbilanz_von_Fahrzeugen.pdf [Accessed: 2020-09-24].

World Bank Open Data 2020. [Online] https://data.worldbank.org [Accessed: 2020-09-4].

Yevdokimov et al. 2018 - Yevdokimov, Y., Chygryn, O., Pimonenko, T. and Lyulyov, O. 2018. Biogas as an alternative energy resource for Ukrainian companies: EU experience. Innovative Marketing 14(2), pp. 7-15; DOI: 10.21511/im.14(2).2018.01. 


\title{
Rozwój rynku samochodów elektrycznych w USA: uwarunkowania makroekonomiczne i prognozy
}

\author{
Streszczenie
}

W artykule zastosowano metody modelowania matematycznego do badania głównych trendów i makroekonomicznych uwarunkowań rozwoju rynku samochodów elektrycznych w latach 2011-2018 na przykładzie USA. Determinanty obejmują czynniki ekonomiczne (PKB), społeczno-ekonomiczne (dochody gospodarstw domowych), energetyczne (zużycie energii elektrycznej) i środowiskowe (emisja $\mathrm{CO}_{2}$ ). Autorzy potwierdzają znaczącą rolę transportu elektrycznego we wzmacnianiu bezpieczeństwa energetycznego kraju ze względu na przejście na technologie energii odnawialnej i ograniczenie zużycia paliw kopalnych. $\mathrm{Na}$ podstawie skonstruowanych równań regresji liniowej ujawniono słabą zależność między liczbą sprzedanych pojazdów elektrycznych a czynnikiem środowiskowym, co można wyjaśnić niewielkim udziałem samochodów elektrycznych w rynku amerykańskim. Utworzony wieloczynnikowy model liniowy wykazał pozytywny wpływ zarówno wzrostu PKB kraju, jak i wzrostu zużycia energii elektrycznej na liczbę sprzedawanych pojazdów elektrycznych. Wzrost dochodów gospodarstw domowych negatywnie wpływa na rozwój rynku ze względu na niedostateczną świadomość konsumentów dotyczącą korzyści płynących z eksploatacji transportu elektrycznego, słabo rozwiniętą sieć stacji ładowania pojazdów elektrycznych, itp. Na podstawie uzyskanego modelu wieloczynnikowego autorzy zbudowali scenariusze rozwoju rynku pojazdów elektrycznych w USA na najbliższe pięć lat: optymistyczny, optymalny i pesymistyczny. W celu realizacji najkorzystniejszych scenariuszy sformułowano rekomendacje dotyczące zarządzania czynnikami rozwoju rynku. Wyniki badania mogą zostać wykorzystane do poprawy polityki publicznej w sektorze transportu i energii w USA, a także w innych krajach do optymalizacji bilansu paliwowo-energetycznego, wzmocnienia niezależności energetycznej państw poprzez rozwój czystego transportu poprzez dostosowanie modelu do specyfiki tych krajów.

SŁOWA KLUCZOWE: polityka rozwoju, elektromobilność, modelowanie sektora transportu, prognoza, rynek 